\title{
Influence of Climate on Annual Production of Seven Cold Desert Forage Species.
}

\author{
NED FETCHER AND M.J. TRLICA
}

\begin{abstract}
Stepwise regression analyses were used to examine the relationships between annual production of seven cold desert forage species and climate variables at different periods of the year. No significant regressions were found for production of Artemisia arbuscula var. nova, Oryzopsis hymenoides, or Sitanion hystrix with precipitation and temperature. For Artemisia tridentata, Atriplex confertifolia, Ceratoides lanata, and Atriples gardeneri, significant $(p<.05)$ regressions were found between annual production and precipitation during the spring months. For Artemisia tridentata and Atriplex confertifolia, mean monthly temperature in March and April also appeared in the equations. Multiple regression was used to test the null hypothesis that the amount of variation in annual production explained by winter (November-February) or spring (March-June) precipitation was equal to zero. No significant $(p<.05)$ linear relationship was found between winter precipitation and production, whereas such a relationship appeared more likely for spring precipitation and production of Artemixia tridentata, Ceratoides lanata, and Atriplex gardeneri.
\end{abstract}

Much of the annual precipitation in the cold desert is received when temperatures are too cold to permit plant growth. Some of the precipitation is stored in the soil and is available for plant uptake during the spring and summer. Winter precipitation is therefore believed to be very important for plant growth the following growing season (Wein and West 1971). This assumption has been supported by studies performed in the cold desert and similar vegetation types. Blaisdell (1958) found that total precipitation received from July through March was correlated with production of grasses, forbs, and shrubs on the Snake River Plains in Idaho. Similarly, Sneva (1977) found that precipitation from July through May was correlated with production of mature crested wheatgrass (Agropyron desertorum) growing on the high desert of eastern Oregon. Although Hutchings and Stewart (1953) found that total annual production was highly correlated with precipitation for the water year (October through September), they did not perform correlation analyses for seasonal precipitation and production.

Investigators who have looked at other vegetation types have come to somewhat different conclusions regarding the importance of winter vs. growing season precipitation. Rogler and Haas (1947) found that precipitation from April through July was correlated with forage production in mixed-grass

\footnotetext{
Authors are graduate research assistant and associate professor, Range Sciencc Department, Colorado State University, Fort Collins, Colorado 80523. Fetcher's current address is Dept. of Bology, Virginia Polytechnic Institute and State University, Blacksburg 24061 .

The authors would like to thank Dr. C. Wayne Cook for permitting the use of his data We also would like to thank Dr. Robin M. Andrews, Dr. Charles D. Bonham, and Dr. Robert G. Woodmansee for their reviews of the manuscript and Dr. Jeffrey B. Birch of the Statistics Department at Virginia Polytechnic Institute for help with the statistics. This study was supported by the Bureau of Land Management, the Boettcher Foundation, and the Colorao State University Experiment Station through Project 100. Experiment Station Journal Paper No. 2361.
}

prairie. At the San Joaquin Experimental Range in the California annual grassland, Duncan and Woodmansee (1975) found poor correlations between early season precipitation and peak forage production and concluded that precipitation had to be adequately distributed through the growing season for maximum production. Working with data from an annual grassland in northern California, Pitt and Heady (1978) found that standing crop in June was influenced most importantly by temperatures in November, December, January, and February, and by fall precipitation. Thus the importance of winter precipitation vs. growing season precipitation may depend to a large extent on the vegetation type and the general pattern of climate.

The present investigation focused on the relationships between production of seven species of the cold desert of northern Utah and climate. Our objectives were to determine the influence of winter and growing season precipitation on the production of individual species and to determine whether temperature during the growing season had any additional effect on production.

\section{Methods}

Production data for seven species were collected from 1962 to 1968 as part of a serics of experiments on the effects of scason and intensity of defoliation on yield and vigor of desert forage species (Cook 1971). The species studied were black sagebrush (Artemisia arbuscula Nutt. var. nova (A. Nels) Cronq.), big sagebrush (Artemisia tridentata Nutt.), shadscale (Atriplex confertifolia (Torr. \& Frem.) S. Wats.), winterfat (Ceratoides lanata (Pursh.) J.T. Howell), Nuttal saltbush (Atriplex gardneri (Moq.) D. Dietr.), Indian ricegrass (Oryzopsis hymenoides Roem. \& Schult.), and squirreltail grass (Sitanion hystrix (Nutt.) J.G. Smith). Ten sampling units of each species were clipped at two sites in northwestern Utah, Curlew Valley and West Kelton, which are about $20 \mathrm{~km}$ apart. The sampling unit was a $0.89-\mathrm{m}^{2}$ circular plot for winterfat and Nuttall saltbush and an individual plant for the other species. To estimate annual production for each species, yield of plants harvested in the winter from a light intensity treatment (either 25 or $33 \%$ removal) was multiplied by a factor of 4 or 3 . These adjusted clipping yields were used to estimate aboveground primary production of each species for the previous growing season.

Monthly measurements of precipitation were taken from rain gauges located at the study sites from 1961 to 1969 (Coyne 1969). Temperature data were taken from the U.S. Weather Service records for Park Valley, Utah, about $30 \mathrm{~km}$ from the Curlew Valley site and 20 $\mathrm{km}$ from the West Kelton site. When these data were not available, the Park Valley temperatures were estimated with regression equations from temperatures measured $50 \mathrm{~km}$ away at Snowville, Utah. Multiple stepwise regression was used to investigate the relationships between production and climate variables. Precipitation was summed for months of the winter and the growing season in various combinations. Mean monthly temperature for March through August was used to represent temperature during the growing season. Mean production at 
the two sites was not significantly $(p<.05)$ different for six of the seven species. Therefore, production data and precipitation data from the two sites were combined for purposes of analysis. The exception was Nuttall saltbush, for which separate analyses were carried out for data from Curlew Valley and West Kelton.

\section{Results}

Production of black sagebrush, Indian ricegrass, and squirreltail grass was not significantly $(p<.05)$ correlated with any of the climate variables. For the other four species, significant regressions between climate variables and mean annual production were found (Table 1). In all cases the variables that entered the multiple regression equations were those associated with weather in the months from March through June, suggesting that spring precipitation acting alone or in combination with spring temperatures may have had more influence on annual production than did winter precipitation.

Table 1. Stepwise multiple regression equations for production $(P)$ of big sagebrush, shadscale, winterfat, and Nuttall saltbrush at Curlew Valley and West Kelton as a function of precipitation $(\mathrm{cm})$ and temperature $\left({ }^{\circ} \mathrm{C}\right)$.

\begin{tabular}{|c|c|c|c|}
\hline Species & & Regression equation & $R^{2}$ \\
\hline Big sagebrush & $\mathrm{P}(\mathrm{g} /$ plant $)$ & $\begin{aligned}= & -172.4+8.76 \times \text { March }- \text { June precipitation } \\
& +19.4 \times \text { Mean March temperature } \\
& +15.0 \times \text { Mean April temperature }\end{aligned}$ & \\
\hline Shadscale & $\mathrm{P}(\mathrm{g} /$ plant $)$ & $\begin{aligned}= & 8.9+2.27 \times \text { April }- \text { May precipitation } \\
& +6.20 \times \text { Mean March temperature }\end{aligned}$ & \\
\hline Winterfat & $\mathrm{P}\left(\mathrm{g} / \mathrm{m}^{2}\right)=$ & $\begin{array}{l}31.0+2.41 \times \text { April }- \text { May precipitation } \\
+4.95 \times \text { June precipitation }\end{array}$ & .71 \\
\hline $\begin{array}{l}\text { Nuttall saltbush } \\
\text { Curley Valley }\end{array}$ & $\mathrm{P}\left(\mathrm{g} / \mathrm{m}^{2}\right)=$ & $\begin{array}{l}13.6+1.01 \times \text { March }- \text { May precipitation } \\
+1.58 \times \text { June precipitation }\end{array}$ & .93 \\
\hline West Kelton & $\mathrm{P}\left(\mathrm{g} / \mathrm{m}^{2}\right)=$ & $61.1+35.9 \times$ March precipitation & .92 \\
\hline
\end{tabular}

To test this hypothesis more explicitly, we performed multiple regressions for annual production using precipitation for the period from November through February and for the period from March through June as independent variables. Partial $F$-tests (Draper and Smith 1966) were used to test the null hypotheses that the amount of variation in annual production explained by winter or spring precipitation was equal to zero. The partial $P$ values and the probabilities of getting larger values by chance are shown in Table 2 . These results indicated that no signifcant $(p<.05)$ linear relationship existed between winter precipitation and production, whereas such a relationship was more likely for spring precipitation and production of big sagebrush, winterfat, and Nuttall saltbush.

\section{Discussion}

The results of these analyses suggest that the variations in annual production were more strongly affected by precipitation events that occurred during the growing season. Mean monthly temperature did not enter into any regression equations with the exceptions of big sagebrush and shadscale. For these two species, increased temperature may have enhanced growth rates in early spring when water was available. Also, increased monthly temperatures may have reflected a greater number of warm days and a faster rate of phenological development, which could have contributed to greater production.

The different species varied greatly in their response to spring precipitation. Winterfat, Nuttall saltbush, and big sagebrush
Table 2. Partial $F$ statistics $(F)$ and probabilities $(p)$ of obtaining greater $F$ statistics by chance for the regression of average annual production of seven cold desert forage species on precipitation from November through February and from March through June.

\begin{tabular}{lccccc}
\hline & $\begin{array}{c}\text { Number } \\
\text { of }\end{array}$ & \multicolumn{2}{c}{$\begin{array}{c}\text { Precipitation } \\
\text { (Nov.-Feb.) }\end{array}$} & \multicolumn{2}{c}{$\begin{array}{c}\text { Precipitation } \\
\text { (March-June) }\end{array}$} \\
Species & observations & $F$ & $p$ & $F$ & $p$ \\
\hline Black sagebrush & 14 & 2.50 & .14 & 0.17 & .69 \\
Big sagebrush & 12 & 3.34 & .10 & 13.7 & .0049 \\
Shadscale & 14 & 0.03 & .86 & 3.21 & .10 \\
Winterfat & 14 & 1.31 & .28 & 20.2 & .0009 \\
Indian ricegrass & 14 & 1.81 & .21 & 0.55 & .47 \\
Squirreltail grass & 14 & 0.51 & .49 & 0.82 & .38 \\
Nuttall saltbush & & & & & \\
$\quad$ Curlew Valley & 7 & 0.27 & .63 & 35.3 & .004 \\
$\quad$ West Kelton & 7 & 0.20 & .68 & 6.58 & .062 \\
\hline
\end{tabular}

responded more than did shadscale. Black sagebrush and the two grasses apparently did not respond at all. It should be noted that production of the two grasses may have been affected by losses between maturation and clipping, depending on the severity of the weather in late summer and fall.

The different responses of the seven species may be the result of differences in physiology and morphology. Pitt and Heady (1978) found a differential response to freezing temperatures for different grass species. They suggested that different patterns of species response occurred because of different physiological requirements for germination and growth. In the present study, the differences in production may be explained by morphological differences in the rooting zone instead of differences in physiology. In a comparison of shadscale and winterfat, Caldwell et al. (1977) found little difference in such physiological characteristics as photosynthetic carbon gain, water use efficiency, and the fraction of the annual water budget used by the plants. On the other hand, Fernandez and Caldwell (1975) found that big sagebrush in Curlew Valley had a shallower root profile than winterfat and shadscale. Winterfat had approximately the same root distribution as shadscale at the shallower depths, but shadscale roots penetrated about $30 \mathrm{~cm}$ deeper. Near Grand Junction, Colo., Nuttall saltbush was found to have to highest proportion of roots near the surface, followed by big sagebrush, winterfat, and shadscale (Branson et al. 1976). It seems likely that species with shallower root distributions such as Nuttall saltbush and big sagebrush were able to utilize soil moisture from spring precipitation events before it evaporated. Consequently, the shallow-rooted species grew more than deep-rooted species in years with high spring precipitation.

For those species that responded to spring precipitation, the equations developed in this study may have some utility in predicting forage production in northwestern Utah. They should be used cautiously, however, because of the variability in precipitation from site to site, the variability in edaphic factors, and the fact that production of some important forage species such as black sagebrush may be poorly correlated with precipitation.

\section{Literature Cited}

Blaisdell, J.P. 1958. Seasonal development and yield of native plants on the upper Snake River Plains and their relation to certain climatic factors. U.S. Dep. Agr. Tech. Bull, No. 1190.68 p.

Branson, F.A., R.F. Miller, and I.S. McQueen. 1976. Moisture relationships in twelve desert shrub communities near Grand Junction, Colorado. Ecology 57:1104-1124. 
Caldwell, M.M., R.S. White, R.T. Moore, and L.B. Camp. 1977. Carbon balance, productivity, and water use of cold-winter desert shrub communities dominated by $C_{3}$ and $C_{4}$ species. Oecologia 29:275-300.

Cook, C.W. 1971. Effects of season and intensity of use on desert vegetation. Utah Agr. Exp. Sta. Bull. No. 483. Logan. 57 p.

Coyne, P.I. 1969. Seasonal trends in total available carbohydrates with respect to phenological stage of development in eight desert range species. $\mathrm{PhD}$ Diss. Utah State Univ., Logan. 164 p.

Draper, N.R., and H. Smith. 1966. Applied Regression Analysis. Wiley, New York. 407 p.

Duncan, D.E., and R.G. Woodmansee. 1975. Forecasting forage yield from precipitation in California's annual rangeland. J. Range Manage. 28:327329.

Fernandez, O.A., and M.M. Caldwell. 1975. Phenology and dynamics of root growth of three cool semi-desert shrubs under field conditions. J. Ecol.

\section{3:703-714.}

Hutchings, S.S., and G. Stewart. 1953. Increasing forage yields and sheep production on intermountain winter ranges. U.S. Dept. Agr. Circ. No. 925. $63 \mathrm{p}$.

Pitt, M.D., and H.F. Heady. 1978. Responses of annual vegetation to temperature and rainfall patterns in northern California. Ecology 59:336-350.

Rogler, G.A., and H.J. Haas. 1947. Range production as related to soil moisture and precipitation on the Northern Great Plains. J. Amer. Soc. Agron. 39:378-389.

Sneva, F.A. 1977. Correlations of precipitation and temperature with spring regrowth and mature crested wheatgrass yields. J. Range Manage. 30:270-275.

Wein, R.W., and N.E. West. 1971. Phenology of salt desert plants near contour furrows. J. Range Manage. 24:299-304. 